\title{
Correction to: A B-spline finite element method for solving a class of nonlinear parabolic equations modeling epitaxial thin-film growth with variable coefficient
}

Dandan Qin 1,2 , Jiawei Tan ${ }^{2,3}$, Bo Liu² and Wenzhu Huang ${ }^{4 *}$

The original article can be found online at https://doi.org/10.1186/ s13662-020-02629-6

"Correspondence: hwenzhu@gmc.edu.cn

${ }^{4}$ School of Biology and Engineering, Guizhou Medical University,

Guiyang, P.R. China

Full list of author information is

available at the end of the article

\section{Correction}

In the original publication of this article [1] the name of the second author is incorrect. The correct name of the second author is Jiawei Tan rather than John Jiawei Tan. The error in this Correction has been updated in the original article.

Author details

${ }^{1}$ Fundamental Department, Aviation University of Air Force, Changchun, P.R. China. ${ }^{2}$ College of Mathematics, Jilin University, Changchun, P.R. China. ${ }^{3}$ School of Mathematics and Statistics, Changchun University of Technology, Changchun, P.R. China. ${ }^{4}$ School of Biology and Engineering, Guizhou Medical University, Guiyang, P.R. China.

\section{Publisher's Note}

Springer Nature remains neutral with regard to jurisdictional claims in published maps and institutional affiliations.

Published online: 21 July 2020

\section{References}

1. Qin, D., et al.: A B-spline finite element method for solving a class of nonlinear parabolic equations modeling epitaxial thin-film growth with variable coefficient. Adv. Differ. Equ. 2020, 172 (2020) https://doi.org/10.1186/s13662-020-02629-6

\section{Springer}

(c) The Author(s) 2020. This article is licensed under a Creative Commons Attribution 4.0 International License, which permits use, sharing, adaptation, distribution and reproduction in any medium or format, as long as you give appropriate credit to the original author(s) and the source, provide a link to the Creative Commons licence, and indicate if changes were made. The images or other third party material in this article are included in the article's Creative Commons licence, unless indicated otherwise in a credit line to the material. If material is not included in the article's Creative Commons licence and your intended use is not permitted by statutory regulation or exceeds the permitted use, you will need to obtain permission directly from the copyright holder. To view a copy of this licence, visit http://creativecommons.org/licenses/by/4.0/ 